\title{
Analisis kesiapan mahasiswa menjadi calon guru profesional berdasarkan standar kompetensi pendidik
}

\author{
Rika Sukmawati \\ Pendidikan Matematika, FKIP, Universitas Muhammadiyah Tangerang, \\ Jl. Perintis Kemerdekaan 1/33 Tangerang \\ rikasukma75@yahoo.com \\ DOI :10.15575/ja.v5i1.4789 \\ Received: 06 Maret 2019; Accepted: 16 Mei 2019; Published: 29 Juni 2019
}

\begin{abstract}
Abstrak
Penelitian ini bertujuan untuk medeskripsikan kemampuan mahasiswa program studi pendidikan matematika dalam menyiapkan diri menjadi guru profesional berdasarkan standar kompetensi pendidik yang dibutuhkan kelak ketika menjadi guru pada mata kuliah microteaching. Melalui microteaching guru diberikan pengetahuan dan keterampilan bagaimana merencanakan dan mempraktikan kegiatan pembelajaran yang akan diberikan kepada siswa agar pembelajaran menjadi bermakna sehingga dapat menjadi guru profesional. Jenis penelitian adalah kualitatif deskriptif dengan subjek penelitian seluruh mahasiswa yang mengambil mata kuliah microteaching semester genap pada tahun akademik 2018/2019. Instrumen yang digunakan adalah lembar penilaian perencanaan pembelajaran, lembar observasi praktik mengajar, lembar penilaian kompetensi pratikan dan catatan kegiatan praktik. Teknik pengumpulan data dengan cara observasi, wawancara dan dokumentasi. Berdasarkan hasil analisis diperoleh gambaran dan kesimpulan bahwa mahasiswa program studi pendidikan matematika pada mata kuliah microteaching sudah mampu menjadi guru profesional berdasarkan kompetensi pendidik yaitu kompetensi pedagogik, kepribadian, profesional dan sosial.
\end{abstract}

Kata Kunci: Guru, Profesional, Microteaching, Pedagogik

\begin{abstract}
This study aims to describe the ability of mathematics education study program students to prepare themselves to become professional teachers based on educator competency standards that are needed later when becoming teachers in microteaching courses. Through microteaching teachers are given the knowledge and skills to become professional teachers. This type of research is descriptive qualitative with research subjects all students taking the even semester microteaching courses in the 2018/2019 academic year. The instruments used were learning planning assessment sheets, teaching practice observation sheets, preliminary competency assessment sheets and notes on practical activities. Data collection techniques using observation, interviews, and documentation. Based on the results of the analysis obtained an overview and conclusion that students of mathematics education study programs in microteaching courses have been able to become professional teachers based on the competence of educators namely pedagogical, personality, professional and social competencies.
\end{abstract}

Keywords: Teachers, Professionals, Microteaching, Pedagogical 


\section{PENDAHULUAN}

Pendidikan merupakan suatu kegiatan sosial yang mempunyai peranan penting dalam kehidupan manusia guna memberikan pengetahuan, keterampilan kepada peserta didik, serta perubahan tingkah laku dan perilaku peserta didik. Pendidikan yang baik dan bermutu sangat dipengaruhi oleh profesional guru dalam melaksanakan tugasnya untuk mencapai tujuan pendidikan. Pendidikan yang diberikan oleh guru sebagai tenaga pendidik memainkan peran penting dalam memberikan dukungan dan memotivasi kepada peserta didik untuk mengikuti kegiatan pembelajaran, karena tujuan utama dari pembelajaran adalah untuk menyiapkan peserta didik menjadi seorang yang berilmu pengetahuan dan terampil yang akhirnya nanti menjadi tenaga kerja yang siap, sukses dan berhasil di dunia kerja.

Era globalisasi sekarang ini, profesionalisme guru merupakan sebuah kebutuhan yang tidak dapat ditunda-tunda lagi seiring dengan meningkatnya persaingan yang semakin ketat. Diperlukan orang-orang yang memang benarbenar ahli dalam bidangnya, sesuai dengan kemampuan yang ditekuni agar setiap orang dapat berperan secara maksimal. Tugas menjadi seorang guru profesional tidaklah mudah. Semua orang bisa menjadi guru, namun guru saat ini haruslah memiliki standar kompetensi yang dapat menjadikan dunia pendidikan lebih bermutu dan berkualitas. Dalam Undang-undang Republik Indonesia (Undang-Undang Republik Indonesia No. 14 tahun 2005, 2005) tentang guru dan dosen menyatakan bahwa guru merupakan pendidik profesional dengan tugas utama mendidik, mengajar, membimbing, mengarahkan, melatih, menilai, dan mengevaluasi peserta didik jalur pendidikan formal mulai dari pendidikan usia dini sampai pendidikan menengah. Guru sangatlah penting guna meningkatkan kemampuan dan potensi yang dimiliki peserta didiknya. Seringkali guru di pandang sebagai sosok sentral dan ujung tombak untuk mencapai tujuan pendidikan.

Guru yang profesional adalah guru yang memiliki kompetensi yang dipersyaratkan mampu melakukan tugas pendidikan dan pengajaran. Guru profesional harus mampu menguasai ilmu pengetahuan mengenai sumber bahan yang akan diajarkan, metode pengajaran dan karaktersitik siswa. Menurut Uno (Uno, 2012) guru yang memiliki kompetensi profesional harus menguasai : 1) Disiplin ilmu pengetahuan sebagai sumber bahan ajar yang akan diajarkan, 2) Pengetahuan mengenai karakteristik siswa, 3) Pengetahuan mengenai filsafat dan tujuan pendidikan, 4) Penguasaan metode dan model pembelajaran, 5) Pengetahuan mengenai prinsip-prinsip teknologi pembelajaran, 6) Pengetahuan mengenai penilaian siswa, 7) Pengetahuan mengenai merencanakan dan menguasai kelas guna kelancaran proses pendidikan.

Guru sebagai seorang pendidik profesional harus memiliki kemampuan kompetensi yang telah distandarkan dan mampu menunjukkan kualitasnya sebagai guru yang profesional, karena kompetensi merupakan sebuah penguasaan kemampuan kerja setiap individu yang mencakup aspek pengetahuan, keterampilan dan sikap kerja yang sesuai dengan standar yang ditetapkan. Standar kompetensi guru yang harus dimiliki berdasarkan Permendiknas (Peraturan Menteri Pendidikan Nasional No. 16 tahun 2007, 2007) tentang standar kualifikasi akademik dan kompetensi guru menjelaskan bahwa standar kompetensi guru ini dikembangkan secara utuh dari empat kompetensi utama, yaitu kompetensi pedagogik, kepribadian, sosial, dan profesional. Keempat kompetensi tersebut terintegrasi dalam profesional guru. Keberhasilan secara profesional yang ditunjukkan guru secara umum menjadi tolak ukur mutu pendidikan yang baik.

Standar kompetensi guru bertujuan untuk mendapatkan jaminan kualitas guru dalam meningkatkan kualitas proses pembelajaran. Dengan adanya standar kompetensi guru, maka tujuan pembelajaran dapat mudah diterapkan dan sesuai dengan yang diharapkan. Keempat standar kompetensi tersebut wajib dimiliki oleh seorang guru yang diperoleh melalui pendidikan profesi.

Kompetensi pedagogik merupakan kompetensi dalam mengelola dan memahami peserta didik dengan menguasai teori-teori tentang pendidikan guna mengembangkan peserta didik untuk mampu mengaktulisasikan 
berbagai potensi yang dimiliki peserta didiknya. kompetensi pedagogik juga merupakan kemampuan menyusun dan mengembangkan rencana pelaksanaan pembelajaran dengan menguasai teknik-teknik dan metode pembelajaran berdasarkan landasan kurikulum pendidikan, mampu melaksanakan pembelajaran yang mendidik dan dialogis dengan memmanfaatkan teknologi pembelajaran dan mampu membuat evaluasi proses dari hasil pembelajaran.

Kompetensi kepribadian merupakan kemampuan individu atau personal yang mencerminkan kepribadian yang dewasa, bijaksana, arif, objektif, berwibawa, stabil, konsisten, displin, jujur, berwawasan luas, bertanggung jawab, berakhlak mulia dan mampu menjadi teladan bagi peserta didiknya karena guru merupakan role model yang di tiru dan di gugu sebagai sumber inspirasi positif bagi peserta didiknya. Selain itu kemampuan mengevaluasi diri sendiri secara objektif dan mengembangkan diri secara mandiri dan berkelanjutan.

Kompetensi sosial merupakan

kemampuan dalam melakukan komunikasi baik secara lisan, tulisan, maupun perilaku yang mampu bekerjasama dan beradaptasi dengan peserta didik, teman sejawat, orang tua peserta didik, tenaga kependidikan, pimpinan satuan pendidikan dan masyarakat yang beranekaragam suku, budaya dan kebiasaan yang berada di sekitar tempat melaksanakan tugas. Kemampuan komunikasi tersebut dilakukan secara efektif, ramah, santun, beradab dan berdasarkan norma yang berlaku serta mampu menggunakan teknologi komunikasi dan informasi secara fungsional dengan menerapkan prinsip-prinsip persaudaraan sejati dan semangat kebersamaan.

Kompetensi profesional merupakan kemampuan dalam menguasaan materi pembelajaran yang diampu secara mendalam dan luas. Penguasaan materi tidak hanya sampai penguasaan materi pelajaran saja, namun juga menguasai materi-materi kurikulum yang berlaku, konsep dan struktur keilmuan, masalah-masalah pendidikan dan memiliki wawasan yang luas terhadap materi tersebut dan materi yang relevan.

Guru profesional yang memiliki standar kompetensi pendidik juga harus dimiliki pada guru yang mengampu bidang studi matematika. Matematika pada dasarnya membantu peserta didik agar berpikir kritis, logis, sistematik, kreatif, bernalar efektif dan efisien yang dapat menumbuhkan sikap displin, bertanggung jawab, percaya diri, terbuka dan rasa ingin tahu yang tinggi. Berdasarkan permendiknas (Peraturan Menteri Pendidikan Nasional No. 16 tahun 2007, 2007), kompetensi yang harus dimiliki guru bidang studi matematika untuk tingkat menengah adalah : 1) Menggunakan bilangan, hubungan antara bilangan, sistem bilangan dan teori bilangan; 2) Menggunakan pengukuran dan penaksiran; 3) Menggunakan logika matematika; 4) Menggunakan konsepkonsep geometri; 5) Menggunakan konsepkonsep statistika dan peluang; 6) Menggunakan pola dan fungsi; 7) Menggunakan konsep-konsep aljabar; 8) Menggunakan konsep-konsep kalkulus dan geometri analitik; 8) Menggunakan konsep dan proses matematika diskrit; 9) Menggunakan trigonometri; 10) Menggunakan vektor dan matriks; 11) Menjelaskan sejarah dan filsafat matematika; 12) Mampu menggunakan alat peraga, alat ukur, alat hitung, piranti lunak komputer, model matematika, dan model statistika. Tugas pendidik di bidang studi matematika yang begitu ideal dan banyak tersebut akan terbantu jika memiliki kemampuan tersebut.

Program studi pendidikan matematika salah satu tujuannya melatih mendidk tenaga pengajar bidang studi matematika menjadi tenaga pendidik yang profesional. Selain kompetensi pendidik yang dimiliki oleh guru bidang studi matematika, keterampilan juga wajib dimiliki oleh seorang tenaga pendidik, menurut Dewanti (Dewanti, 2012) ada tiga indikator keterampilan yang harus di miliki oleh tenaga pendidik yaitu: 1) mendesain materi ajar matematika sekolah menengah pertama, atas, dan yang sederajat; 2) terampil menggunakan strategi pembelajaran matematika dijenjang pendidikan menengah; 3) menerapkan dan mengembangkan materi ajar matematika yang mendasari pendalaman keislaman serta pembelajarannya.

Guna mendukung pencapaian indikator keterampilan tersebut, maka diperlukan mata kuliah yang didalamnya terdapat ilmu kependidikan dan kependidikan matematika. 
Hal tersebut agar dapat membantu mahasiswa Program Studi Pendidikan Matematika dalam mengembangkan keilmuannya sehingga menjadi calon tenaga pendidik khususnya di bidang matematika yang memiliki nilai, sikap, pengetahuan dan keterampilan sebagai tenaga profesional kependidikan sesuai dengan misi dan tugas Program Studi Pendidikan Matematika. Mata kuliah yang terdapat dalam kebutuhan tersebut adalah salah satunya adalah mata kuliah microteaching.

Pembelajaran microteaching menurut Hidayah (Hidayah, 2018) merupakan suatu program pelatihan untuk menyiapkan mahasiswa agar mengusai kompetensi keguruan, sehingga dapat mengemban tugas dan tanggung jawab secara profesional. Microteaching merupakan kegiatan berlatih dalam menguasai keterampilan dasar mengajar yang merupakan proses pembelajaran yang dilakukan secara sederhana dan singkat dalam bagian demi bagian dengan kontrol yang cermat. Tiap bagian dilakukan secara cermat dan tepat sehingga diperoleh kemampuan yang tuntas dan optimal. Dalam pembelajaran microteaching dapat dilakukan dalam bentuk sebenarnya dengan menggunakan peserta didik sebenarnya menjadi peserta didik, atau dapat juga menggunakan mahasiswa sebagai peserta didik.

Microteaching bertujuan untuk memberikan kesempatan kepada mahasiswa sebagai calon tenaga pendidik untuk berlatih mempraktikkan beberapa keterampilan dasar mengajar di depan teman-temannya dalam suasana yang constructive, supportive, dan bersahabat sehingga mendukung kesiapan mental, keterampilan dan kemampuan performance yang terintegrasi untuk bekal praktik mengajar sesungguhnya di sekolah nantinya. Dengan mengikuti pembelajaran microteaching mahasiswa memiliki pengalaman serta kesiapan untuk menjadi guru nanti sebagai calon guru.

Kesiapan mahasiswa untuk menjadi guru profesional sangat penting karena dengan memiliki kesiapan dapat meminimalisir kesalahan yang terjadi saat menjalani profesinya. Kesiapan calon guru sangat menentukan kualitas guru nantinya, semakin berkualitas gurunya maka akan semakin berkualitas mutu pendidikan. Kesiapan mahasiswa menjadi calon guru profesional merupakan keadaan yang menunjukkan bahwa mahasiswa sudah memenuhi persyaratan yang diwajibkan untuk menjadi guru yang profesional.

Calon guru profesional dibutuhkan kesiapan dan banyak faktor yang mempengaruhi kesiapan tersebut. Menurut Yuniasari(Yuniasari, 2017)faktor-faktor yang mempengaruhi kesiapan seorang calon guru dapat dikelompokkan menjadi 2 (dua) yaitu : 1) faktor internal yang meliputiminat menjadi guru; motivasi; kapasitas intelektual; pengetahuan; dan keterampilan. 2) faktor eksternal yang meliputi informasi tentang dunia kerja; pengaruh dari berbagai lingkungan (Keluarga, sekolah, dan teman sebaya); pengalaman-pengalaman yang didapatkan dari berbagai kegiatan yang menunjang terbentuknya kesiapan untuk menjadi seorang guru seperti Praktik Pengalaman Lapangan (PPL).

Kesiapan menjadi guru dengan kemampuan maksimal perlu dimiliki untuk melaksanakan tugas utamanya sebagai seorang guru profesional. Kesiapan yang perlu dilakukan seorang guru berupa kemampuan penguasaan materi pelajaran, kemampuan fisik dan mental, menurut Maipita dan Mutiara (Maipita \& Mutiara, 2018). Oleh karena itu calon guru sebaiknya sejak sedini mungkin perlu dipersiapkan secara matang agar siap menjadi guru dan menjalankan profesinya dengan optimal dan penuh tanggungjawab. Persiapan itu dimulai semenjak seorang calon guru mengikuti masa perkuliahan diperguruan tinggi.

Berdasarkan latar belakang diatas, maka perlu dilakukan penelitian untuk melihat sejauhmana kesiapan mahasiswa sebagai calon guru profesional dengan rumusan masalah adalah bagaimanakah gambaran kesiapan mahasiswa menjadi calon guru profesional berdasarkan standar kompetensi pendidik dengan tujuan penelitian adalah untuk mengetahui gambaran kesiapan mahasiswa menjadi calon guru profesional berdasarkan standar kompetensi pendidik. Penelitian ini hanya dibatasi untuk menganalisis kesiapan mahasiswa program studi pendidikan matematika Universitas Muhammadiyah Tangerang menjadi calon guru profesional 
berdasarkan standar kompetensi pendidik pada mata kuliah microteaching.

\section{METODE}

Jenis penelitian yang digunakan adalah penelitian kualitatif dengan jenis metode penelitian kualitatif deskritif dengan tujuan untuk memdeskripsikan kesiapan mahasiwa yang mengampu mata kuliah microteaching sebagai calon guru profesional yang berdasarkan standar kompetensi pendidik Subjek penelitian ini adalah mahasiswa program studi pendidikan matematika Universitas Muhammadiyah Tangerang yang mengampu mata kuliah microteaching tahun akademik 2018/2019 sebanyak 90 orang.

Data yang digunakan dalam penelitian menggunakan dua jenis data yaitu 1) Data primer merupakan data yang diperoleh dari tangan pertama yang dikumpulkan secara langsung dari sumbernya berupa data yang didapatkan dari hasil observasi praktik kegiatan pembelajaran microteaching mahasiswa, hasil penilain perangkat mengajar mahasiswa, hasil penilain kompetensi mahasiswa dan hasil wawancara, 2) Data sekunder merupakan data yang diperoleh tangan kedua yang sudah dikumpulkan oleh beberapa orang untuk tujuan penelitian berupa foto-foto ketika pelaksanaan praktik kegiatan pembelajaran dan wawancara.

Teknik pengambilan data yang dilakukan dalam penelitian ini adalah observasi praktik kegiatan pembelajaran, dokumentasi perangkat mengajar yang disiapkan mahasiswa untuk kegiatan pembelajaran dan kompetensi mahasiswa serta wawancara dengan mahasiswa.

Instrumen penelitian yang digunakan adalah lembar observasi praktik kegiatan pembelajaran, lembar penilain kompetensi kegiatan pembelajaran, lembar penilain perangkat mengajar yang disiapkan mahasiswa untuk praktik, catatan seluruh kegiatan. Teknik analisis penelitian yang digunakan terdiri dari tiga tahapan, yaitu : 1) Reduksi data, merupakan kegiatan memilahmilah data yang diperoleh disesuaikan dengan fokus penelitian. Data yang diperoleh berupa hasil observasi, dokumentasi dan wawancara kepada mahasiswa. 2) Penyajian data, merupakan melampirkan hasil penelitian agar data terorganisir sesuai masalah penelitian. 3) Penarikan kesimpulan, merupakan kesimpulan yang diperolah berdasarkan hasil penelitian. Triangulasi yang peneliti lakukan adalah triangulasi sumber dengan menghubunghubungkan semua sumber data yang diperoleh baik data primer maupun data sekunder.

\section{HASIL DAN PEMBAHASAN}

Mata kuliah microteaching memiliki prasyarat mata kuliah yang sudah diselesaikan dan ditempuh yaitu Strategis Belajar dan Mengajar Matematika, Media Pembelajaran, dan Evaluasi pembelajaran. Banyaknya prasyarat mata kuliah yang harus di tempuh mahasiswa dengan tujuan agar mahasiswa memiliki kemampuan dasar sebelum melakukan persiapan simulasi mengajar pada mata kuliah microteaching.

Praktik mengajar pada mata kuliah microteaching sebelum dilaksanakan, sebelumnya mahasiswa diberikan pengetahuan mengenai teknik dasar mengajar dan simulasi mengajar agar mahasiswa mempunyai gambaran bagaimana teknik dan cara mengajar yang baik. Materi praktik mengajar yang perlu disiapkan mahasiswa adalah untuk tingkat sekolah menengah yaitu SMP dan SMA.

Mahasiswa diberikan kebebasan untuk memilih materi yang di kuasai agar mahasiswa lebih siap ketika praktik mengajar dengan persyaratan tidak ada materi yang sama dengan temannya dengan tujuan memperkayakan pengalaman mahasiswa pada semua pokok bahasan matematika pada tingkat SMP dan SMA.

Kegiatan praktik mengajar saat berlangsung, jika mahasiswa melakukan kesalahan fatal seperti grogi, tidak dapat berbicara, tidak dapat menguasai kelas dan tidak menguasai materi, maka mahasiswa diberikan kesempatan untuk satu kali mengulang dengan tujuan agar mahasiswa bisa benar-benar optimal mengeluarkan kemampuannya saat praktik. Berdasarkan analisis yang telah dilakukan diperoleh gambaran sebagai berikut:

1. Penilaian Perangkat Mengajar 
Penilaian perangkat mengajar yang disiapkan mahasiswa sebelum melakukan praktik microteaching meliputi : 1) Program tahunan, 2) Program semester : terdapat semester ganjil atau genap berdasarkan pokok bahasan yang akan diajarkan mahasiswa berada di semester ganjil atau genap, 3) Rencana Pelaksanaan Pembelajaran (RPP) meliputi : a) Identitas; b) Kompetensi Inti; c) Kompetensi dasar; d) Indikator pencapaian kompetensi dasar; e) Tujuan pembelajaran; f) metode/model/strategi pembelajaran yang digunakan; g) Tahapan pembelajaran meliputi kegiatan : pendahuluan, inti dan penutup; h) Sumber belajar/media yang digunakan i) Evaluasi penilain siswa, 4) Bahan ajar meliputi : a) Lembar Kerja Siswa (LKS) meliputi : Identitas, Kompetensi dasar, Indikator pencapaian kompetensi dasar, tahapan penyelesaian soal; b) Alat peraga elektronik/manual; c) Media pembelajaran eletronik, 5) Instrumen evaluasi penilain siswa.

Hasil analisis dari penilain perangkat mengajar yang disiapkan mahasiswa sebelum melakukan praktik mengajar diperoleh data secara umum mahasiswa mampu menyusun perangkat mengajar. Dari 90 mahasiswa, 27\% (24) mahasiswa memperoleh kategori sangat baik, 46\% (42) mahasiswa memperoleh kategori baik dan hanya 27\% (24) mahasiswa memperoleh kategori kurang baik. Dari 26\% yang masuk dalam kategori kurang baik atau mampu diantaranya disebabkan mahasiswa tidak membuat secara lengkap perangkat yang tentukan, yaitu : 1) mahasiswa tidak membuat LKS sebagai salah satu bahan ajar meliputi; soal yang terdapat di dalam LKS tidak sesuai dengan materi yang akan diajarkan dan LKS dibuat tidak berdasarkan ketentuan yang telah ditetapkan yaitu tidak ada identitas; kompetensi dasar, indikator pencapain kompetensi dasar dan tahapan penyelesaian soal. LKS sangat diperlukan sebagai salah satu alat bantu yang digunakan dalam kegiatan belajar mengajar berlangsung. LKS juga berfungsi untuk melihat apakah yang diajarkan sesuai dengan lembar kerja siswanya dan tahapan penyelesaian soal sesuai dengan kaidah dasar ilmu matematika secara hirarki. 2) Mahasiswa tidak membuat model pembelajaran berdasarkan sintaksnya pada tahapan pembelajaran yang terdapat dalam RPP. Contohnya model pembelajaran Problem
Based Learning (PBL) dalam tahapan pembelajarannya tidak menggunakan sintaks yang berlaku pada model pembelajaran PBL. Tahapan pembelajaran sangat penting sekali fungsinya untuk melihat tahapan apa yang akan dilakukan saat mengajar nantinya sesuai dengan model pembelajaran yang digunakan dalam RPP.

\section{Penilain Praktik Mengajar}

Penilain praktik mengajar yang dilakukan yaitu : 1) Penampilan, meliputi : a) Berpakaian rapih dan sopan layaknya seorang guru (batik, blazer, atau kemeja dengan dasi untuk mahasiswa laki-laki); b) Menggunakan sepatu pantofel; c) Memakai rias wajah tipis untuk mahasiswa perempuan, 2) Kegiatan Pendahuluan meliputi : a) Memberi salam; b) Doa dan Absensi; c) Memberikan motivasi; d) Menjelaskan kompetensi dasar dan indikator yang akan dicapai e) Menjelaskan manfaat dan menghubungkan materi pelajaran dalam kehidupan sehari-hari, 3) Kegiatan Inti yaitu melakukan kegiatan pembelajaran sesuai dengan model/ metode/ strategi/ pendekatan yang digunakan sesuai dengan yang tercantum didalam RPP, 4) Kegiatan Penutup meliputi : a) Melakukan kegiatan konfirmasi; b) Melakukan tes akhir kepada peserta didik; c) Pemberian tugas rumah kepada peserta didik.

Hasil analisis dari penilain praktik mengajar yang dilakukan mahasiswa saat melakukan praktik mengajar diperoleh data secara umum mahasiswa mampu melakukan praktik mengajar. Dari 90 mahasiswa, 28\% (25) mahasiswa memperoleh kategori sangat baik, 38\% (34) mahasiswa memperoleh kategori baik dan hanya 34\% (31) mahasiswa memperoleh kategori kurang baik. Dari 34\% yang masuk dalam kategori kurang baik atau mampu diantaranya disebabkan : 1) Mahasiswa kurang menguasai kelas sehingga saat mengajar terlihat kaku dan tidak luwes sehingga tidak komunikatif dan beriteraksi aktif dengan peserta didik. Penguasaan kelas merupakan yang sangat penting diperlukan sebagai guru agar terjadi komunikasi dua arah antara peserta didik dan gurunya karena peserta didik sebagai objek saat mengajar merupakan benda hidup yang mampu berkomunikasi secara aktif, 2) Mahasiswa tidak mengikuti secara tepat model/ metode/ strategi/ pendekatan pembelajaran dalam 
tahapan pembelajaran yang telah dituliskan dalam RPP sehingga kegiatan pembelajaran tidak sesuai dengan yang dicantumkan dalam RPP. Model/ metode/ strategi/ pendekatan yang telah dicantumkan dalam RPP merupakan tahapan yang pembelajaran yang sesuai dengan materi pokok yang akan diajarkan kepada peserta didik, jika tidak mengikuti apa yang terdapat dalam RPP maka tujuan pembelajaran tidak akan tercapai sesuai yang diharapkan. Kegiatan pembelajaran tidak optimal dilakukan sehingga pencapaian penilaian akhir hasil belajar peserta didik pada akhirnya juga tidak sesuai dengan harapan.

\section{Penilian Kompetensi}

Penilaian kompetensi diukur berdasarkan standar kompetensi pendidik yaitu kompetensi pedagogik, kompetensi kepribadian, kompetensi sosial dan kompetensi profesional.

Hasil analisis secara umum dari 90 mahasiswa yang memiliki kompetensi berdasarkan standar kompetensi pendidik sebagai berikut ini :

\section{1)Kompetensi Pedagogik}

Kompetensi pedagogik meliputi:

Kemampuan membimbing peserta didik; (2) Kemampuan mengelola kelas; (3) Penguasaan media dan teknologi; (4) Kemampuan pembuatan perangkat mengajar berdasarkan prinsip-prinsip pengembangan kurikulum; (5) Berpersepsi positif terhadap peserta didik; (6) Kemampuan menyusun instrumen penilaian peserta didik. Hasil analisis diperoleh data secara umum dari 90 mahasiswa adalah $28 \%$ (25) mahasiswa memperoleh kategori sangat baik, 42\% (55) mahasiswa memperoleh kategori baik dan hanya 10\% (10) mahasiswa memperoleh kategori kurang baik.

Mahasiswa yang memperoleh kategori kurang baik atau mampu pada kompetensi pedagogik, dikarenakan masih ada mahasiswa kurang mampu menguasai sintaks pada model/ metode/ strategi/ pendekatan pembelajaran yang digunakan pada tahapan refleksi diri; (6) Kemampuaan pemanfaatan iptek dalam pembelajaran matematika. Hasil analisis diperoleh data secara umum dari 90 mahasiswa adalah 23\% (21) mahasiswa pembelajaran sehingga tahapan-tahapan yang perlu diperhatikan pada model yang digunakan tidak sesuai. Penguasaan sintaks pada tahapan pembelajaran sangat diperlukan untuk mengetahui langkah apa saja yang dilakukan dalam proses pembelajaran sehingga dapat mengevaluasi apakah model/ metode/ strategi/ pendekatan yang digunakan efektif dan efisien pada materi yang diajarkan.

\section{2) Kompetensi Kepribadian}

Kompetensi kepribadian meliputi : (1) Kedisplinan; (2) Kesopanan dan kelancaran komunikasi; (3) Kewibawaan; (4) Kearifan mengambil keputusan; (5) Menjadi tauladan; (6) Kemampuan mengendalikan diri. Hasil analisis diperoleh data secara umum dari 90 mahasiswa adalah 60\% (54) mahasiswa memperoleh kategori sangat baik dan 40\% (36) mahasiswa memperoleh kategori baik. Pada kompetensi kepribadian menunjukkan bahwa mahasiswa sudah mampu memiliki kompetensi kepribadian.

\section{3) Kompetensi Sosial}

Kompetensi sosial meliputi : (1) Kemampuan menyampaikan pendapat; (2) Mudah beradaptasi dan bergaul; (3) Toleransi yang tinggi; (4) Bekerjasama; (5) Menerima kritik, saran dan pendapat orang lain; (6) Kemampuan berkomunikasi. Hasil analisis diperoleh data secara umum dari 90 mahasiswa adalah $67 \%$ (60) mahasiswa memperoleh kategori sangat baik dan 33\% (30) mahasiswa memperoleh kategori baik. Pada kompetensi sosial menunjukan bahwa mahasiswa sudah mampu memiliki kompetensi sosial.

\section{4) Kompetensi Profesional}

Kompetensi profesional meliputi : (1) Penguasaan materi matematika; Keluasaan wawasan keilmuan; (3) Kemampuan mengkaitkan matematika dengan kehidupan sehari-hari; (4) Kemampuan mengikuti perkembangan ilmu pengetahuan; (5) Ketersedian melakukan

memperoleh kategori sangat baik, 48\% (43) mahasiswa memperoleh kategori baik dan hanya 29\% (26) mahasiswa memperoleh kategori kurang baik. 
Mahasiswa yang memperoleh kategori kurang baik pada kompetensi profesional, dikarenakan masih ada mahasiswa yang kurang mampu menguasai materi pelajaran matematika. Mahasiswa masih melihat catatan kecil (textbook) saat mengajar, menjelaskan materi salah konsep dan lompat-lompat tidak runut berdasarkan hirarki konsep matematika dasar. Penguasaan materi saat mengajar sangat penting karena materi yang akan disampaikan kepada peserta didik jika salah memberikan konsep kepada peserta didik, maka peserta didik akan salah terus pada

\section{REFERENSI}

Dewanti, S. S. (2012). Analisis kesiapan mahasiswa program studi pendidikan matematika sebagai calon pendidik profesional. Seminar Nasional Pendidikan Matematika Surakarta (hal. 17-27). Surakarta: 9 Mei 2012.

Hidayah, N. (2018). Analisis kesiapan mahasiswa prodi pendidikan guru madrasah ibtidaiyah sebagai calon pendidik profesional. Terampil, 138155.

Maipita, I., \& Mutiara, T. (2018). Pengaruh minat menjadi guru dan praktik program lapangan (ppl) terhadap kesiapan menjadi guru pada mahasiswa jurusan ekonomi Universitas Negeri Medan TA. 2017/2018. Ekonomi Pendidikan, 3443.

Peraturan Menteri Pendidikan Nasional No. 16 tahun 2007. (2007). Standar jenjang selanjutnya dan peserta didik akan kesulitan untuk memahami materi pada jenjang berikutnya.

\section{KESIMPULAN}

Berdasarkan hasil dan pembahasan penelitian, maka diperoleh kesimpulan bahwa mahasiswa sudah siap dan mampu menjadi calon guru profesional berdasarkan standar kompetensi pendidik yaitu kompetensi pedagogik, kompetensi kepribadian, kompetensi sosial dan kompetensi profesional.

kualifikasi akademik dan kompetensi guru . Jakarta: Departemen Pendidikan Nasional.

Undang-Undang Republik Indonesia No. 14 tahun 2005. (2005). Guru dan Dosen. Jakarta: Presiden Republik Indonesia.

Uno, H. (2012). Profesi kependidikan problema, solusi dan reformasi pendidikan di indonesia. Jakarta: Bumi Aksara.

Yuniasari, T. (2017). Pengaruh minat menjadi guru, lingkungan keluarga, dan praktik pengalaman lapangan ( $p p l$ ) terhadap kesiapan menjadi guru akuntasi mahasiswa pendidikan akuntansi angkatan 2013 FE UNY. Yogyakarta: Skripsi Program Studi Pendidikan Akuntansi Fakultas Ekonomi Universitas Negeri Yogyakarta. 